\title{
Gymnastic and Warm Compression Effect on Dysmenohrea Adolescence Overcoming Behavior
}

\author{
Deswani, Sri Maryani ${ }^{*}$, Rita Ismail \\ Nursing Departemen Health Polytechnic Ministry of Health Jakarta III \\ Indonesia \\ Corresponding author's email: desika_64 [AT] yahoo.co.id
}

\begin{abstract}
Changes that occur in young women entering puberty are the functioning of all reproductive organs, one of which is marked by the onset of menstruation that can cause pain during menstruation which is also called dysmenorrhea. Dysmenorrhea is a condition where a woman experiences pain before menstruation and during menstruation. Dysmenorrhea can interfere with learning activities and indirectly can also affect the productivity and quality of life of adolescents. The purpose of the study was to determine the effect of gymnastics and warm compresses on the management of dysmenorrhea and pain scale. The research design used the quasiexperimental design with the non-randomized pretest-posttest control group. The study population was 60 respondents, the results of the study of the effect of warm gymnastics and compress in reducing teenage dysmenorrhea dysmenorrhea with controlled gymnastics and warm compresses Gymnastics and warm compresses can be recommended for teenagers and as part of nursing interventions to deal with dysmenorrhea.
\end{abstract}

Keywords - dysmenorrhea, warm compresses, gymnastics, adolecence

\section{INTRODUCTION}

Dysmenorrhea (dysmenorrhoea) is a condition experienced by women, especially in adolescents before menstruation or during menstruation. The nature and degree of pain vary, ranging from mild to severe, infrequent pain accompanied by nausea, body aches, and even can interfere with daily activities [15]. Dysmenorrhea begins with the process of menstruation where there is a stimulation of muscle contraction. Contraction of the uterine muscles makes blood flow to the uterine muscles become reduced which results in increased activity of the uterus to meet their needs for a smooth blood flow, also the muscles of the uterus that lack blood will stimulate the nerve endings so that it feels pain. The pain is not only felt in the uterus but also felt in other parts of the body that get the same nerves as the uterus. Therefore, discomfort is also felt in parts of the body used to defecate, urinate, and pelvic floor muscles and the area around the lower spine. This is also referred to as referral pain or referred pain for adolescents. Dysmenorrhea experienced by adolescents is related to previous ovulation and there is a relationship between uterine muscle contractions and prostaglandin secretions (primary dysmenorrhea).

Dysmenorrhea (dysmenorrhoea) is a condition experienced by women, especially in adolescents before menstruation or during menstruation. The nature and degree of pain varies, ranging from mild to severe, infrequent pain accompanied by nausea, body aches, and even can interfere with daily activities [15] Pain is not only felt in the uterus, but also feels in other parts of the body that get the same nerves as the uterus. Therefore, discomfort is also felt in parts of the body used to defecate, urinate, and pelvic floor muscles and the area around the lower spine. This is also referred to as referral pain or referred pain for adolescents. Dysmenorrhea experienced by adolescents is related to previous ovulation and there is a relationship between uterine muscle contractions and prostaglandin secretions (primary dysmenorrhea).

Efforts to treat non-pharmacological dysmenorrhea according to [11] and [7[ include 1) Compress with a warm bottle on the part that feels cramped in the abdomen or the back of the waist 2) Drink warm drinks that contain high calcium. 3) Avoid drinking alcoholic beverages, coffee and ice cream. 4) Rubbing the affected stomach or waist. Set the knee-chest position so that the uterus is hanging down. 5) Relaxation techniques by breathing deeply and exhaling through the mouth.[9] found that there was a significant influence between exercise with complaints of pain during menstruation. According to [12]. xercise or exercise is one of the psychotherapies to convince women that their complaints do not endanger life, and will pass once the blood is released smoothly. The entire manuscript, including mathematical equations, tables, and figures must be prepared in electronic form and submitted as Word for Windows files. Use only fonts that come with Windows software. For the text use Times New Roman size 10. For all special characters (e.g., 
Greek characters) use the font Symbol. Line spacing is single; spacing after paragraphs is $6 \mathrm{pt}$; first line is indented .2 inches; text alignment is justified. Use carriage returns only to end headings and paragraphs, not to break lines of text. Verify the correct spelling for the final version with the Spelling and Grammar function of Word.

In the Introduction section, present clearly and briefly the problem investigated, with relevant references. The main results should be enunciated.

\section{METHOD}

Based on the problems and research objectives to be achieved, the type of research used was a quasi-experimental study with a non-randomized pretest-posttest design with control group design. The study was conducted by giving intervention using guidelines for managing dysmenorrhea in the intervention group and comparing the results of the intervention with the group without intervention or control group. The sampling technique uses purposive sampling where sampling is based on a particular consideration made by the researcher with the characteristics and conditions of the population that have been known in advance [10], with consideration of sample selection through criteria. Inclusion criteria in this study were adolescents who had primary dysmenorrhea on the first day of menstruation in the last six months, were willing to only do gymnastics and warm compresses as a reliever for dysmenorrhea in the intervention group, the teenager knew the estimated menstrual cycle in the last three months, and was willing to become a respondent. The sample calculation in this study uses an independent two-proportion hypothesis test with a significance level of 5\% and a test strength of $80 \%$, and obtained a sample size of at least 27 . To anticipate the possibility of a sample, drop out, $10 \%$ of each sample was added to the intervention group and the control group was 30 , so the total sample in this study were 60 adolescents.

The tool that will be used is a questionnaire to determine the behavior of respondents in overcoming dysmenorrhea, a questionnaire made by researchers with reference to the concepts and theories of menstrual behavior and pain and behavior in managing dysmenorrhea. Thus, this questionnaire is still not standard and needs to be tested so that it can be used. Questionnaire trials will be planned at SMP Negeri 272 which is a school that is almost as characteristic as National Middle School 259. Then the validity and reliability of the questionnaire were tested to find out whether the questions in the questionnaire were clear, not hesitant, objective, not distorted and relevant to the research and the number of questions was enough to collect data. Test results are obtained. Instrument reliability: reliable (Alpha Cronbach > alpha table) Alpha Cronbach $=0.643$ and $>$ alpha table $=0.349$ 2. Validity of questions on instrument: all questions are valid because all questions have alpha> alpha table, but questions no 3,5,6,7, 8.9 and 10 must be corrected

\section{RESULT}

Table 1 shows the characteristics of respondents (age) are homogeneous in the intervention group and the control group is homogeneous.

Based on TABLE 2: Analysis of equality of time, duration, and previous experience, knowledge and attitudes toward dysmenorrhea showed pain before menstruation and knowledge in managing dysmenorrhea and attitudes toward dysmenorrhea showed the equivalence of both groups.

At point 3 shows the results of the dependency test with Chi-Square obtained $p=0.01$ in the intervention group, so it can be concluded that the intervention of warm compresses and gymnastic activity in reducing the level of dysmenorrhea.

The results of the significance test in Table 4 found that the group of adolescents who received the intervention had a 29,557 times chance of experiencing a decrease in pain during menstruation. And has a chance of dealing with dysmenorrhea correctly.

TABLE 1: Age-Based Homogeneity Test in Intervention Groups and Control Groups

\begin{tabular}{llccccc}
\hline Variabel & Group & $\mathrm{N}$ & Mean & Median & SD & P-value \\
\hline Age & Intervention & 30 & 12.70 & 13 & 0.596 & 0.059 \\
& Control & 30 & 12.53 & 12 & 0.776 & \\
\hline
\end{tabular}


TABLE e 2: Analysis of equality of time, duration, and previous experience, knowledge and attitudes towards dysmenorrhea

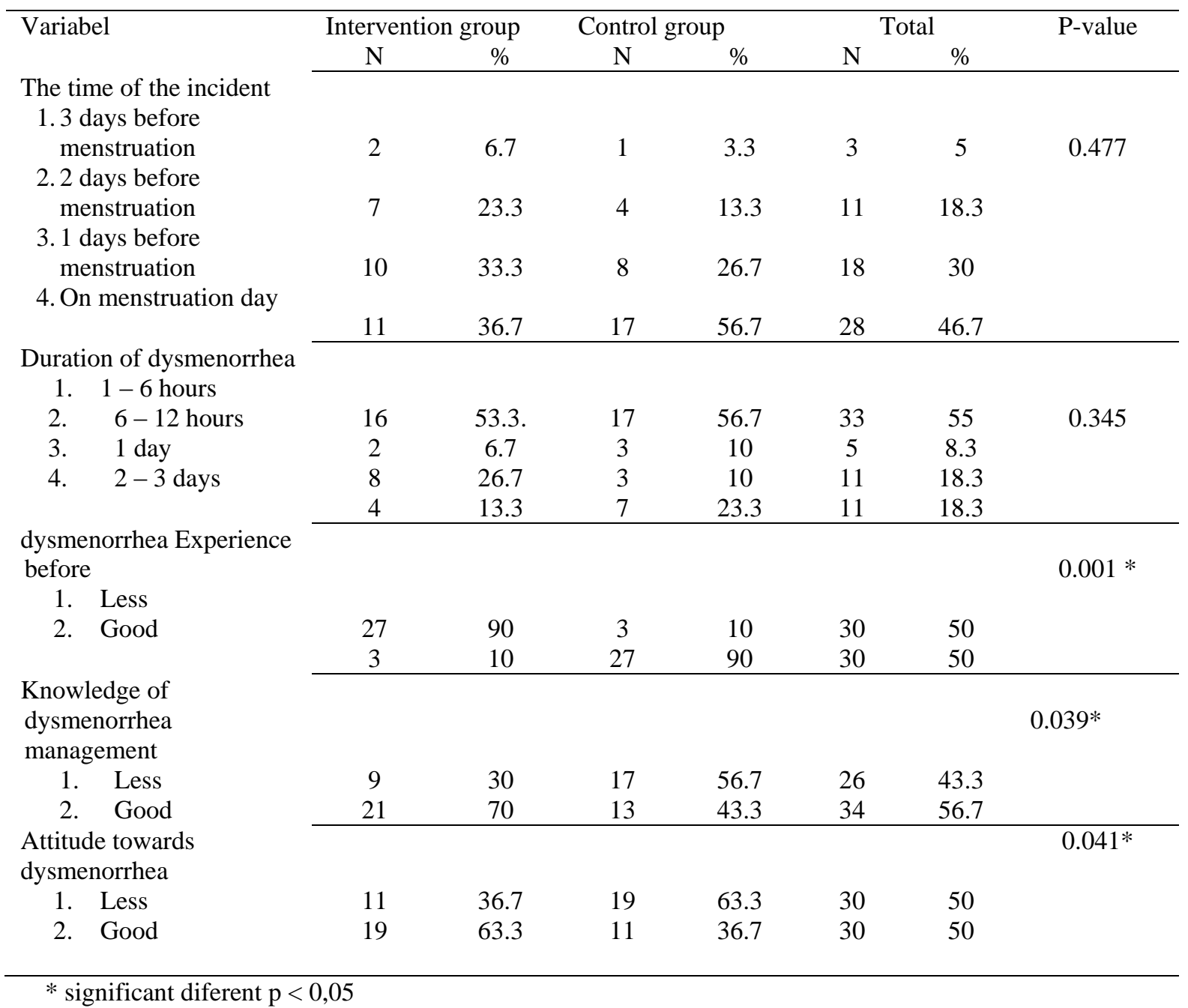

TABLE 3: Differences in pain levels and pain management before and after intervention in the intervention and control

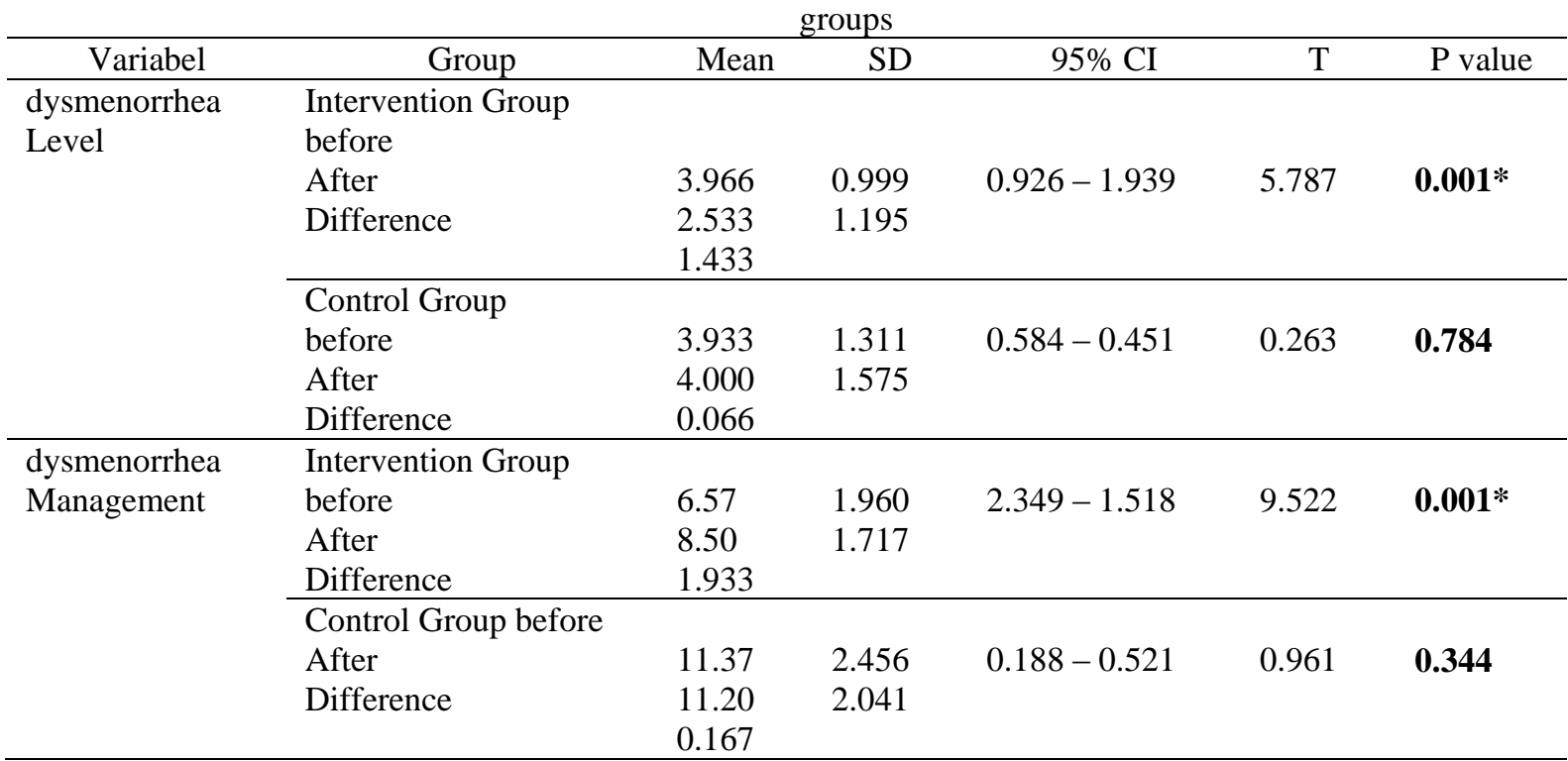


TABLE 4: Multivariate Final Model: Effect of student characteristics on Pain Level and dysmenorrhea management

\begin{tabular}{|c|c|c|c|c|c|}
\hline $\begin{array}{c}\text { Variabel } \\
\text { Independent }\end{array}$ & $\begin{array}{c}\text { Variabel } \\
\text { Dependent }\end{array}$ & $\begin{array}{c}\text { Mean } \\
\text { Square }\end{array}$ & df & $\mathbf{F}$ & $P$ value \\
\hline \multirow[t]{2}{*}{ Age } & $\begin{array}{ll}\text { - } & \text { dysmenorrhea } \\
& \text { level }\end{array}$ & 0.061 & 1 & 0.038 & 0.847 \\
\hline & $\begin{array}{l}\text { - dysmenorrhea } \\
\text { management }\end{array}$ & 5,309 & 1 & 2.608 & 0.112 \\
\hline \multirow[t]{2}{*}{$\begin{array}{l}\text { dysmenorrhea } \\
\text { experiance }\end{array}$} & $\begin{array}{l}\text { - dysmenorrhea } \\
\text { level }\end{array}$ & 29.557 & 1 & 18.369 & 0.001* \\
\hline & $\begin{array}{l}\text { - dysmenorrhea } \\
\text { management }\end{array}$ & 19.133 & 1 & 9.400 & 0.003* \\
\hline \multirow{2}{*}{$\begin{array}{l}\text { dysmenorrhea } \\
\text { knowledge }\end{array}$} & - dysmenorrhea & 0.031 & 1 & 0.019 & 0.890 \\
\hline & $\begin{array}{l}\text { dysmenorrhea } \\
\text { management }\end{array}$ & 0.005 & 1 & 0.002 & 0.962 \\
\hline \multirow[t]{2}{*}{$\begin{array}{l}\text { dysmenorrhea } \\
\text { behavior }\end{array}$} & $\begin{array}{l}\text { - dysmenorrhea } \\
\text { level }\end{array}$ & 1.880 & 1 & 1.168 & 0.285 \\
\hline & $\begin{array}{l}\text { dysmenorrhea } \\
\text { management }\end{array}$ & 0.118 & 1 & 0.058 & 0.811 \\
\hline
\end{tabular}

\section{DISCUSSION}

Description of the characteristics of respondents.

Menstrual characteristics of respondents were found in the intervention group, the majority $(36.7 \%)$ stated that dysmenorrhea occurred during menstruation as well as the majority control group 56.7\% said that pain occurred at the time of menstruation, although some stated that one or two days before menstruation had felt pain, this is in accordance with the opinion of [13] which states that at the time of menstruation the uterus contracts strongly to remove the endometrial cells that are shed due to the release of the uterine lining in the form of menstrual blood. During menstruation uterine contractions last long enough to result in fatigue of the muscles of the uterine muscles and this causes a feeling of cramps and pain in the lower abdomen, waist and around the genitals to the inner thigh area. Menstrual characteristics based on the duration of dysmenorrhea or duration of pain felt by respondents from the majority intervention group for $1-6$ hours (53.3\%) and in the control group also the majority $1-6$ hours $(56.7 \%)$.

Pain experience is an event where respondents before menstruation have experienced pain which is felt more painful than dysmenorrhea experienced now. This is in accordance with[7] 's opinion that someone who has experienced severe pain in the past, the level of pain that is felt when the next pain will be compared to the pain he has experienced. So that past pain experiences will affect the level of pain experienced during menstruation, with the same level or scale of pain being received or responded differently by each person. In addition, individuals who have experienced severe pain will prepare themselves both physically and mentally to adapt to the pain experienced and have better knowledge to deal with the dysmenorrhea that arises.

Respondents' knowledge and attitude in pain management

According to [17]), a teenager starts menstruating at an average age of 10 to 12 years. The results of the study found that the majority of respondents' knowledge and attitudes in managing dysmenorrhea were quite good in the intervention group while in the control group knowledge and attitudes of the majority of respondents were not good. This is likely to be associated with exposure to information both from school and from parents.

Knowledge and attitude of poor respondents are likely because on average they only get menstruation several times so they do not have good knowledge about menstruation and menstrual handling. This also affects his attitude in managing dysmenorrhea. After puberty with many changes experienced by adolescents, one of them is menstruation, coupled with the presence of pain complaints that make teenagers limited to playing and normal activities. According to [7] in developmental psychology, it is said that attitude is a belief, emotion and a decision that can be accounted for rationally and responsibly for reasons that are believed to be true. If the attitude is not good towards something, the reception response becomes less good. With the attitude that is not good for dysmenorrhea, the response of adolescents to the level of dysmenorrhea and handling dysmenorrhea will affect. 
The results showed that the intervention of warm compresses and gymnastics proved effective in reducing pain in adolescents with dysmenorrhea. The ability to treat dysmenorrhea in the respondent before and after the intervention in [14] intervention group showed a significant difference seen from $p=0.001$ ). This is in accordance with research by[14] which states that there is a significant relationship between the level of knowledge of menstruation with menstrual handling behaviour, the opinion of [11] that someone who has been trained or training will have the ability to do an action that has been taught. according to the researchers, this could happen because respondents had received education in the form of counselling about menstrual physiology, causes of pain and how to deal with pain, and respondents were given textbooks about menstruation, dysmenorrhoea and warm compresses and given warm exercises and compress twice before posting test. To get sufficient ability must have the good basic knowledge, be guided and carried out repeatedly. Education and training through management packages for dysmenorrhea treatment with dysmenorrhoea and warm compresses will provide choices for teenagers to overcome dysmenorrhea non-pharmacologically.

The results of the analysis showed that there were significant differences in pain levels in the intervention group before and after the intervention with a combination pain management package of dysmenorrhoea and warm compresses with $\mathrm{p}$ $=0.001$ while there was no significant difference in the control group. Dysmenorrhea is a condition experienced by adolescents before menstruation or during menstruation. The results of this analysis are in accordance with [13] stated that there was a significant relationship between warm compresses and pain levels. Giving warm compresses in areas of pain has been shown to result in the dilation of blood vessels and blood circulation, which has an impact on providing comfort and reducing pain. Based on the research of Diana Ika (2013), about the effect of dysmenorrhoea gymnastics on pain intensity the results showed no significant changes with $p=0,000$. in the intervention group who experienced $77 \%$ moderate pain to mild pain after dysmenorrhoea exercise. This is also in line with the research of [16] which states that dysmenorrhoea gymnastics has a significant effect on pain intensity before and after the action. According to [5] by exercising the body will produce endocrine which functions as a natural sedative, which can cause comfort, relax so as to reduce pain. With the presence of physical exercise in the form of exercise, it can increase muscle strength, muscle flexibility. In addition, it can improve appetite and increase memory. Harry ${ }^{[4]}$ also stated that the exercise of the body produces endorphins. Endorphins are produced in the brain and spinal nervous system. This hormone functions as a natural sedative, causing a sense of comfort. Increased endorphin levels in the body can reduce pain during contractions. Physical exercise is proven to increase endorphin levels four to five times in the blood so that the more exercise you do, the higher the levels of endorphins. When a person exercises, the endorphins will come out and be captured by the receptors in the hypothalamus and limbic system which function to regulate emotions. Endorphin enhancement has been shown to be closely related to decreased pain, increased memory, improved appetite, sexual ability, blood pressure and breathing ${ }^{[4]}$, so exercise / physical exercise can be effective in reducing pain problems, especially dysmenorrhea.

Physical exercise is the physical activity to make the body's condition improve its health and maintain physical health. According to [9] ${ }^{]}$stated that physical exercise has a significant relationship with a decrease in the level of muscle fatigue. Adolescents with dysmenorrhea will experience muscle cramps, especially in the lower abdomen that is cyclic due to strong and long contractions in the uterine wall resulting in muscle fatigue and physical inactivity, so exercise is needed to eliminate muscle cramps [9]. This means that doing exercise will reduce muscle fatigue/fatigue, especially in the lower abdomen, so that pain intensity can decrease. However, the results of this study were not supported by study[3] which stated that there was no relationship between dysmenorrhea and exercise / physical exercise. In this study also explained if smaller studies ( $<500$ respondents) were more likely to produce positive relationships. One exercise that can be done to reduce the intensity of dysmenorrhea (dysmenorrhea) is by performing an abdominal stretching exercise. The abdominal stretching exercise performed during dysmenorrhea to increase muscle strength, endurance, and muscle flexibility [22] can improve fitness, optimize capture power, improve mental and physical relaxation, increase the development of body awareness, reduce muscle tension ( cramps), reduce muscle pain, and reduce dysmenorrhea (dysmenorrhea)[1], to reduce muscle tension, improve blood circulation, reduce anxiety, feeling depressed, and fatigue, improve mental alertness, reduce the risk of injury, simplify work, integrate thoughts into the body, and make feelings better ${ }^{[2]}$, so that it is expected to reduce dysmenorrhea (dysmenorrhea) in women. Muscle stretching exercises or stretching can also improve body posture and avoid the pain that occurs in the neck, shoulders, and back 12]

The purpose of muscle stretching exercises is to help increase oxygenation or the process of oxygen exchange and carbon dioxide in the cell and to stimulate the lymphatic drainage system flow, so as to increase muscle flexibility by restoring the muscles to their natural length and can maintain their function properly and improve elasticity or flexibility of body tissue and reduce cramping in muscles [12]. The results of this study are also in line with the opinion of [10]) exercises such as by moving the pelvis, with the knee-chest position, and breathing exercises can be useful for reducing dysmenorrhea. The same thing was stated by [23] that one way to overcome dysmenorrhea is to take or perform a knee chest position so that the uterus hangs down, and take deep deep breaths for relaxation. This is also supported by [2]) which states that relaxation of skeletal muscles is believed to reduce pain by relaxing muscle tension that supports pain. 
Based on multi-variance test with Mantova it was found that the experience affected the level of dysmenorrhea and the handling of dysmenorrhea. The effect of pain experience with pain level is very significant with a value of $p=0.001$ this proves that the experience of pain is one of the strongest factors compared to other variables. This is in accordance with [8] 's opinion that someone who has experienced severe pain in the past, the level of pain felt when the next pain will decrease because they already have a way to deal with pain. So the experience of past pain will affect the level of pain experienced during menstruation. Dysmenorrhea experience also has a major effect on pain management abilities. The results showed that the experience of pain and pain management had a significant effect with $p=0.001$. Respondents who have experienced pain before having more knowledge to deal with the pain that arises from dysmenorrhea experienced now. individuals who have experienced severe pain will prepare themselves both physically and mentally to adapt to the pain experienced and have better knowledge to deal with the dysmenorrhea that arises

The purpose of muscle stretching exercises is to help increase oxygenation or the process of oxygen exchange and carbon dioxide in the cell and to stimulate the lymphatic drainage system flow, so as to increase muscle flexibility by restoring the muscles to their natural length and can maintain their function properly and improve elasticity or flexibility of body tissue and reduce cramping in muscles [12]. The results of this study are also in line with the opinion of [10] exercises such as by moving the pelvis, with the knee-chest position, and breathing exercises can be useful for reducing dysmenorrhea. The same thing was stated by [23] that one way to overcome dysmenorrhea is to take or perform a knee chest position so that the uterus hangs down, and take deep deep breaths for relaxation. This is also supported by [2] which states that relaxation of skeletal muscles is believed to reduce pain by relaxing muscle tension that supports pain.

Based on multi-variance test with Mantova it was found that the experience affected the level of dysmenorrhea and the handling of dysmenorrhea. The effect of pain experience with pain level is very significant with a value of $p=0.001$ this proves that the experience of pain is one of the strongest factors compared to other variables. This is in accordance with [7] 's opinion that someone who has experienced severe pain in the past, the level of pain felt when the next pain will decrease because they already have a way to deal with pain. So the experience of past pain will affect the level of pain experienced during menstruation. Dysmenorrhea experience also has a major effect on pain management abilities.

The results of this study are also in line with the opinion of [10] exercises such as by moving the pelvis, with the kneechest position, and breathing exercises can be useful for reducing dysmenorrhea. The same thing was stated by [23] that one way to overcome dysmenorrhea is to take or perform a knee chest position so that the uterus hangs down, and take deep deep breaths for relaxation. This is also supported by [2] which states that relaxation of skeletal muscles is believed to reduce pain by relaxing muscle tension that supports pain.

Based on multi-variance test with Mantova it was found that the experience affected the level of dysmenorrhea and the handling of dysmenorrhea. The effect of pain experience with pain level is very significant with a value of $p=0.001$ this proves that the experience of pain is one of the strongest factors compared to other variables. This is in accordance with [8] 's opinion that someone who has experienced severe pain in the past, the level of pain felt when the next pain will decrease because they already have a way to deal with pain. So the experience of past pain will affect the level of pain experienced during menstruation. Dysmenorrhea experience also has a major effect on pain management abilities. The results showed that the experience of pain and pain management had a significant effect with $p=0.001$. Respondents who have experienced pain before having more knowledge to deal with the pain that arises from dysmenorrhea experienced now. individuals who have experienced severe pain will prepare themselves both physically and mentally to adapt to the pain experienced and have better knowledge to deal with the dysmenorrhea that arises

Based on the results of this study researchers argue that the experience of previous pain and attitudes towards pain affect the level of pain and the handling of dysmenorrhea that is done by adolescents. Based on the explanation above it was found that the results of the study answered the major hypothesis which states that the intervention of warm compresses and gymnastics plays a role in reducing the level of pain in adolescents with dysmenorrhea. The results also answered the minor hypothesis which states that there is a significant difference in the level of dysmenorrhea after the intervention of warm compresses and gymnastics in the intervention group and the control group

\section{CONCLUSION}

Characteristics of respondents age in the intervention group found that the proportion of the most respondents were at the age of 12-14 years. Whereas in the control group the proportion of the most respondents was at the age of 12-14 years. The result of the homogeneity test showed that age and class variables were homogeneous in both groups. In the intervention group, the highest proportion of pain intensity was in mild pain, whereas in the control group the pain was severe. There were significant differences in pain intensity between the intervention group and the control group. The intervention of warm compresses and gymnastics in reducing the level of pain in adolescents with dysmenorrhea. 
Adolescents should use the intervention of warm compresses and gymnastics in reducing dysmenorrhea, while advice for nurses as counsellors / care providers/educators to apply the intervention of warm compresses and gymnastics to adolescents who experience dysmenorrhea in the practice of independent nursing services based on non-pharmacological therapy. Suggestions for the next researcher need to be similar to the larger sample and, it is recommended to be able to continue the research with a new design form involving tribal and cultural variables in different regions.

Table 5: Project selection matrix rules

\begin{tabular}{c|c|c}
\hline & Table 5: Project selection matrix rules \\
\hline if Project strength is & And Project attractiveness is & Then the project rank is \\
\hline Low & Low & Low \\
Low & Medium & Low \\
Low & High & Medium \\
Medium & Low & Low \\
Medium & Medium & Medium \\
Medium & High & High \\
High & Low & Medium \\
High & Medium & High \\
High & High & High \\
\hline
\end{tabular}

\section{ACKNOWLEDGEMENT}

I would like to thank the director of polyethnic Ministry of Health, Jakarta III and the research unit who gave me the opportunity and funded the competitive grant research in 2018 with the title "the influence of gymnastics and warm compresses on the behavior of managing menstrual pain in young women". I would like to express my gratitude to the commission of ethics in polyethnic, Ministry of Health, Jakarta III, and to students who have helped in collecting data in this study. I am sure this research is still lacking. I really thank all of them, so the results of this study can be poured in scientific articles. and don't forget I also thanked family and friends who helped me a lot in completing the research and this article according to the time

\section{REFERENCES}

[1] Alter, M.J., "Sport stretch”,Florida International University, Florida, 2008.

[2] Brunner \& Suddarth's., Textbook of Medical-Surgical Nursing",by Hinkle, Janice L.; Cheever, Kerry H.Publisher: Lippincott Williams \& Wilkins Edition: $13^{\text {th }}, 2013$

[3] Blakey, H., Chisholm, C., Dear, F., Harris, B., Hartwell, R., Daley, A.J., \& Jolly, K). "Is exercise associated with primary dysmenorrhoea in young women”. BJOG An International Journal of Obstetrics \& Gynaecology”, 117, 222-224. USA, 2009.

[4] Daley, A.J), "Exercise and primary dysmenorrhoea: A comprehensive \& critical review of the literature", Sport Medicine: Adis Data International, 38 (8), 659-67, 2008.

[5] Harry, "Mekanisme endorphin dalam tubuh".Diperoleh dari http://klikharry.files.com, 2007.

[6] Istiqomah. "Efektivitas senam dismenore dalam mengurangi dismenore pada remaja putri di smu n 5 semarang The Effectiveness of Dismenore Gymnastics for the Teenagers in SMU N 5 Semarang, 2019

[7] Kartono.K, "Psikologi Anak, Psikologi Perkembangan” Mandar Maju, Bandung 1998.

[8] Jayanti dkk.. Deskripsi Faktor-faktor yang Mempengaruhi Kesiapan Anak dalam menghadapi

[9] Jhamb, M., Weisbord, S.D., Steel, J.L. \& Unruh,M, "Fatigue in patients receiving maintenance dialysis: A review of definitions, measures and contributing factors", AMJ Kidney Dis, 52 (2), 353-365, 2008.

[10] Marilyn J. Hockenberry, David Wilson, Cheryl C RodgersWong's "Essentials of Pediatric Nursing 9th Edition" Elsevier Mosby 2016

[11] Notoatmojo, "Metodologi Penelitian Kesehatan"; Rineka Cipta, Jakarta, 2009.

[12] Purwanti S., 'Deskripsi Faktor-faktor yang Mempengaruhi Kesiapan Anak dalam menghadapi Menarche di SDN I Kretek Kec. Paguyungan Kabuapten Brebes”, Jurnal Ilmiah Kebidanan, Vol 3. No 1, Edisi Juni 2011

[13] Proverawati, S Misaro "Menarche menstruasi pertama penuh makna" , Nuha Medika Yogyakarta, 2009

[14] Ratna Dewi, Menarche di SDN I Kretek Kec. Paguyungan Kabuapten Brebes 2011. Jurnal Ilmiah Kebidanan , Vol 3. No 1, Edisi Juni, 2012

[15] Santoso, "Angka kejadian nyeri haid pada remaja Indonesia". Diperoleh dari http:// www.info-sehat.com/insi. 2008.

[16] .Setyorini Yuyun, \&Satino. Efektifitas Senam Dengan Modul Dalam Mengurangi Dismenorhoe Pada Remaja Di Kota Surakarta,Jurnal Terpadu Ilmu Kesehatan, vol 5 . No 2, Surakarta, 2015.

[17] Sukarni. and Margaret, “ buku ajar keprawatan maternitas , nurhamedika Jogjakarta 2013 
[18] Wiknjosastro, Hanifa .Ilmu Kandungan. Yayasan Bina Pustaka Sarwono Prawiroharjo: Jakarta;2007. Rahayu S.'Pengaruh kompres hangat terhadap dismenore primer pada mahasiswi semester VII S1 Keperawatan Universitas Muhammadiyah Semarang. Universitas MuhammadiyahA' Semarang, 2010.

[19] Ratna dewi hubungan pengetahuan menstruasi dengan perilaku kesehatan remaja puteri tentang menstruasi di smpn i trenggalek, 2013

[20] Simamora, Debora L. "hubungan tingkat stres terhadap siklus menstruasi pada remaja sma di lingkungan labuhan deli kecamatan medan marelan di stikes imelda medan tahun 2014". jurnal ilmiah kebidanan imelda,, vol. 2, n. 2, aug. 2018

[21] Thermacare.. Abdominal stretching exercises for menstrual pain. Diperoleh dari http:// www.chiromax.com/Med. $\underline{2010}$.

[22] Sharma, A., Taneja, D.K., Sharma, P., \& Saha R. (2008). Problems related to menstruation and their effect on daily routine of students of a medical college in Delhi, India. Asia Pacific Journal Of Public Health, 2008 